\title{
Where does her mood come from? An organic approach to a once functional patient
}

\author{
De onde vem seu humor? Uma abordagem orgânica para um paciente previa- \\ mente funcional
}

Pablo Eduardo Pereira Dutra, ${ }^{1}$ Wagner de Sousa Gurgel, ${ }^{1}$ Renato Alves Higa, ${ }^{1}$ Carolina Costa $^{2}$

\begin{abstract}
Objective: To report the rare development of manic symptoms in a patient with schizophrenia and discuss its differential diagnosis.

Case description: Diagnostic criteria were based on the International Classification of Diseases, 10th edition (ICD-10). A 63-year-old female (diagnosed with schizophrenia since she was 28) was brought to the emergency room with symptoms consistent with manic episode and physical examination suggestive of thyrotoxicosis. Graves' disease was confirmed by subsequent laboratory tests. She was treated successfully with radioiodine ablation, leading to full remission of manic symptoms.

Comments: Schizophrenia is a chronic disease that affects about $1 \%$ of the population worldwide. The main symptoms of the disorder are altered affection, delusions, and hallucinations. Graves' disease is an autoimmune condition in which antibodies increase the production and release of thyroid hormones. There are reports about the development of mood symptoms in patients with Graves' disease that remit with adequate treatment.
\end{abstract}

Keywords: Schizophrenia, Graves' disease, mood symptoms, radioiodine, thyroid gland, schizoaffective disorder.

\section{Introduction}

Schizophrenia is a disorder of aberrant neurodevelopment with minor physical anomalies, neurological soft signs, and abnormalities of brain structure and function. ${ }^{1}$ It is marked by deficits in both working memory and long-term memory tasks,

\section{Resumo}

Objetivo: Relatar um caso raro de desenvolvimento de sintomas maníacos em uma paciente com esquizofrenia e discutir o diagnóstico diferencial desses sintomas.

Descrição do caso: Foram utilizados como base os critérios diagnósticos da Classificação Internacional de Doenças, $10^{a}$ edição (CID-10). Paciente de 63 anos do sexo feminino e com diagnóstico de esquizofrenia desde os 28 anos foi levada a emergência com sintomas compatíveis com episódio de mania e exame físico sugestivo de tireotoxicose. Doença de Graves foi confirmada por exames subsequentes. A paciente foi tratada com sucesso com ablação por iodo radioativo, levando à remissão dos sintomas maníacos.

Comentários: A esquizofrenia é uma doença crônica que afeta cerca de $1 \%$ da população mundial. Os principais sintomas do transtorno são o embotamento afetivo, alucinações e delírios. A doença de Graves é uma doença autoimune em que o estímulo humoral aumenta a produção e liberação de hormônios pela tireoide. Há relatos na literatura sobre o desenvolvimento de sintomas maníacos em pacientes com doença de Graves, os quais remitem mediante tratamento adequado.

Descritores: Esquizofrenia, doença de Graves, sintomas de humor, radioiodo, tireoide, transtorno esquizoafetivo.

disturbances in thinking, emotional reaction, and social behavior, including illusions and hallucinations. ${ }^{1}$ Graves' disease, in turn, was first described by Robert Graves in $1835^{2}$ and has a prevalence of $1 \%$ in the general population. ${ }^{3}$ The relationship between Graves' disease and psychiatric symptoms is known since the 19th century, when Parry \& Graves described behavioral changes

\footnotetext{
${ }^{1}$ Resident physician in Psychiatry, Department of Psychiatry, Centro Psiquiátrico do Rio de Janeiro (CPRJ), Rio de Janeiro, RJ, Brazil. ${ }^{2}$ Chief psychiatrist, Department of Psychiatry, CPRJ, Rio de Janeiro, RJ, Brazil.

Financial support: none.

Submitted Nov 17 2014, accepted for publication Mar 27 2015. No conflicts of interest declared concerning the publication of this article.

Suggested citation: Dutra PEP, Gurgel WS, Higa RA, Costa C. Where does her mood come from? An organic approach to a once functional patient. Trends Psychiatry Psychother. 2015;37(2):100-103. http://dx.doi.org/10.1590/2237-6089-2014-0053
} 
associated with hyperthyroidism, namely, dysphoria, anxiety, tremor, emotional lability, restlessness, fatigue, rapid speech, delirium, paranoia, and mania. ${ }^{4}$

In 2010, Boelaert et al. assessed the coexistence of Graves' disease or Hashimoto's thyroiditis and other autoimmune diseases in 2,791 and 495 patients, respectively, and found coexisting disorders in $9.7 \%$ of the former and in $14.3 \%$ of the latter. ${ }^{5}$ The increase in free thyroxine (fT4) blood levels caused by Graves' disease has been shown to worsen and even cause many psychiatric symptoms, e.g., mania, anxiety, depression, and psychosis. ${ }^{3}$

Delusions and hallucinations are both associated with changes in dopamine neurotransmission in patients with schizophrenia. ${ }^{6-8}$ We report a rare case of development of manic symptoms in a female patient with schizophrenia who had never had mood symptoms before.

\section{Case description}

Written informed consent was obtained from the patient for publication of this case report.

A 63-year-old, thin, black female patient presented at the emergency room reporting euphoria, hyperthymia, racing thoughts, excessive talking, insomnia, increased goal-directed activity, aggressiveness, careless appearance, and delusions of being pregnant. The patient claimed that she wanted to go home with her husband and that she did not want to live with her relatives. The relatives informed that she had never been married or pregnant; nor did she have a history of manic episodes. The family also denied alcohol or any drug consumption. She had been repeatedly hospitalized in the previous 2 years. The family lived in a slum and came from a low socioeconomic background.

The patient developed schizophrenia at the age of 28. Her past records showed no evidence of manic or depressive episodes. She had a niece with bipolar affective disorder and a brother with drug addiction. On physical examination, she was thin, presented tachycardia (average heart rate of 112), a moist skin, poor hygiene, and was carelessly dressed. No goiter/thyroid enlargement was observed at the time of admission.

Laboratory tests showed normal hemoglobin and hematocrit levels, suppressed thyroid-stimulating hormone (TSH), and increased levels of fT4, antithyrotropin receptor antibody (TRAb), and antithyroperoxidase antibody (anti-TPO) (Table 1).

Echocardiography showed normal dimensions of heart cavities, preserved systolic and diastolic functions, mild mitral and tricuspid insufficiency, and normal pericardium and inferior vena cava. Doppler ultrasound showed a thyroid with normal volume, irregular contours, parenchymal heterogeneity, and multiple hypoechoic areas. No nodules or cysts or observed. The right lobe of the gland measured $37 \times 21 \times 15 \mathrm{~mm}$ (volume 6.1 $\mathrm{cc}$ ), the left lobe $35 \times 15 \times 11 \mathrm{~mm}$ (volume $3.1 \mathrm{cc}$ ), and the isthmus $17 \times 13 \times 7 \mathrm{~mm}$ (volume $0.8 \mathrm{cc}$ ); estimated thyroid volume was $10.0 \mathrm{cc}$. There were no satellite lymph nodes. Doppler ultrasound also revealed preserved thyroid vascularity, which did not allow us to rule out Graves' disease or chronic thyroiditis. According to the patient's medical records, she developed Graves' disease in 2012, but was not taking the medications and had missed many appointments with psychiatrists and endocrinologists.

While hospitalized, she was given oral haloperidol (15 mg daily), promethazine (50 mg daily), propranolol (80 mg daily), sodium valproate (500 mg daily), and propylthiouracil (200 mg daily). After 2 weeks, manic symptoms ceased, but she was still delusional about husband and babies; oral valproate was then withdrawn. She was seen by an endocrinologist and prepared for radioablation of the thyroid gland. She received $12 \mathrm{mCi}$ of radioiodine ( $\mathrm{Na131 \textrm {I }})^{9}$ in June 2014.

Subsequent laboratory tests were obtained to quantify serum fT4 levels (Table 1) and introduce oral levothyroxine. After 4 months of oral therapy with Na131I, the patient started taking $88 \mathrm{mcg}$ daily of levothyroxine. The patient became stable, with no mood symptoms, exhibiting blunted affect. Delusions diminished but did not cease completely.

Table 1 - Patient's laboratory results

\begin{tabular}{|c|c|c|c|c|c|c|c|c|c|c|}
\hline & $\begin{array}{c}\text { Nov } 12 \\
2012\end{array}$ & $\begin{array}{c}\text { Oct } 21 \\
2013\end{array}$ & $\begin{array}{c}\text { Jan } 21 \\
2014\end{array}$ & $\begin{array}{c}\text { Feb } 19 \\
2014\end{array}$ & $\begin{array}{c}\text { Mar } 28 \\
2014\end{array}$ & $\begin{array}{c}\text { May } 22 \\
2014\end{array}$ & $\begin{array}{c}\text { Jun } 02 \\
2014\end{array}$ & $\begin{array}{c}\text { Jul } 27 \\
2014 \\
\end{array}$ & $\begin{array}{c}\text { Aug } 21 \\
2014\end{array}$ & $\begin{array}{c}\text { Sep } 08 \\
2014\end{array}$ \\
\hline Hemoglobin $(12.0-16.0 \mathrm{~g} / \mathrm{dL})$ & 9.6 & 11.0 & 10.9 & 13.2 & 13.3 & 13.5 & 13.8 & 13.1 & 11.8 & 13.3 \\
\hline Hematocrit (36-46\%) & 31 & 34 & 33.9 & 41.5 & 42.1 & 45.0 & 47.7 & 41.2 & 36.9 & 43.3 \\
\hline TSH $(0.45-4.50 \mu \mathrm{IU} / \mathrm{mL})$ & $<0.01$ & $<0.01$ & 0.01 & $<0.01$ & $<0.01$ & 0.47 & 0.98 & 1.19 & 0.46 & 9.73 \\
\hline fT4 (0.9-1.7 ng/dL) & 5.7 & 3.2 & 2.3 & 2.2 & 0.8 & 1.0 & 0.7 & 0.8 & 0.9 & 0.6 \\
\hline Anti-TPO $(<34.0 \mathrm{U} / \mathrm{mL})$ & & 157.0 & 154.6 & & & 111.8 & & & & \\
\hline $\operatorname{TRAb}(<1.0 \mathrm{U} / \mathrm{L})$ & & & & & 18.3 & & & & & \\
\hline
\end{tabular}

Anti-TPO = anti-thyroperoxidase antibody; fT4 = free thyroxine; TRAb = anti-thyrotropin receptor antibody; TSH = thyroid-stimulating hormone. 


\section{Discussion}

Our search of the literature was performed using the PubMed/MEDLINE database, the Cochrane Database of Systematic Reviews, and textbooks. In Graves' disease, antibodies produced against TSH receptors cause an increase in thyroid hormone release. Graves' disease is the cause of $60-90 \%$ of all cases of thyrotoxicosis. ${ }^{10,11}$ The elevated fT4 levels observed in the condition are known to cause a myriad of psychiatric symptoms, including mania with psychotic features. ${ }^{3,4,12,13}$ The cooccurrence of endocrine and nervous system disorders has long been reported. ${ }^{13}$

Patients meeting criteria for schizophrenia spectrum disorders have more autoimmune thyroid diseases than other psychiatric patients. ${ }^{14}$ Also, hyperthyroidism is known to be highly frequent among patients over the age of 60,15 and psychosis may be the first symptom of the disease. ${ }^{16}$ A hyperthyroiditic state, as observed in Graves' disease, may worsen the clinical presentation and symptoms of psychosis that were not present before.

It has been proposed that schizophrenia may be caused by maternal exposure to stress during pregnancy, molecular mimicry (infections and/or immune activation), nutritional deficiencies, obstetric complications, and use of cannabis. ${ }^{1}$ Disturbances in dopamine neurotransmission are responsible for the delusions and hallucinations present in the disorder.

Nitric oxide (NO) is important for many cell functions, including neurotransmission and thyroid hormonogenesis. NO derives from the conversion of L-arginine; NO levels can become altered in certain conditions, leading to the accumulation of free radicals (hydrogen peroxide, peroxynitrite) and causing the so called oxidative stress. ${ }^{1}$ Severe oxidative stress is observed in patients with schizophrenia, with decreased NO levels due to high neuronal activity. ${ }^{1}$ Treatment of schizophrenia with antipsychotics can decrease the level of free radicals and oxidative stress. ${ }^{17}$ Among the free radicals, hydrogen peroxide plays an important role in thyroid hormonogenesis, ${ }^{1,10,11}$ because it is necessary for the oxidation of iodide into iodine, as well as for the production of thyroid hormones.

The study conducted by Akiibinu et al. found an association between overproduction of free radicals and increased levels of thyroid hormone in patients with schizophrenia, leading to hyperthyroidism. In our case, even though our patient was diagnosed with schizophrenia, a high level of TRAb was also found, allowing the diagnosis of Graves' disease to be confirmed (Table 1).

Our patient could have been misdiagnosed as hyperthyroiditic with schizophrenia or schizoaffective disorder, which are the differential diagnoses for psychotic patients with high fT4 levels and showing affective symptoms. However, she did not have a history of thyroid disease, and had never presented any mood symptoms before the current occasion.

Patients with schizoaffective disorder present symptoms characteristic of both schizophrenia and affective disorders. ${ }^{18}$ In the case here described, both the patient's medical records and the family denied the occurrence of any affective symptom before. Indeed, while the patient's serum fT4 levels were high, her behavior was compatible with the diagnosis of schizoaffective disorder. However, the mood symptoms ceased after normalization of fT4 levels and withdrawal of valproate treatment. Also, manic symptoms did not reemerge after the withdrawal of sodium valproate, even while she was still hyperthyroiditic. These observations suggest that her psychiatric diagnosis falls somewhere on a continuum between schizophrenia and mood disorders. ${ }^{18}$ The unique finding of this report is the development of affective symptoms during thyrotoxicosis in a patient previously diagnosed with schizophrenia.

\section{Conclusion}

High serum levels of thyroid hormones may be a feature of schizophrenia. Some studies have shown an association between altered thyroid hormones and a high level of oxidative stress in patients with schizophrenia. The high production of free radicals in schizophrenia is responsible for the increased level of thyroid hormones in these patients.

Graves' disease, the leading cause of thyrotoxicosis, is an autoimmune disease. According to Radhakrishnan et al., autoimmune thyroiditis is more commonly seen in patients with schizophrenia spectrum disorders when compared to those with mood disorders. ${ }^{14}$

The present case report described the rare development of affective symptoms in a patient previously diagnosed with schizophrenia who developed Graves' disease at an advanced age. It is widely known that thyroid diseases can trigger psychiatric symptoms (e.g., anxiety, depression, mania, and psychosis) in previously healthy patients. In psychotic patients, thyrotoxicosis can trigger other psychiatric symptoms or worsen the primary disease; this finding justifies thyroid blood testing in psychotic patients. Further studies are necessary to elucidate the pathological process involved in these cases.

\section{References}

1. Akiibinu MO, Ogundahunsi OA, Ogunyemi EO. Inter-relationship of plasma markers of oxidative stress and thyroid hormones in schizophrenics. BMC Res Notes. 2012;5:169. 
2. Graves RJ. Newly observed affection of the thyroid gland in females. Lond Med Surg J. 1835;7:516-7.

3. Bunevicius R, Prange AJ Jr. Psychiatric manifestations of Graves' hyperthyroidism, pathophysiology and treatment options. CNS Drugs. 2006;20:897-909.

4. Peiris AN, Oh E, Diaz S. Psychiatric manifestations of thyroid disease. South Med J. 2007;100:773-4.

5. Boelaert K, Newby PR, Simmonds MJ, Holder RL, Carr-Smith JD, Heward JM, et al. Prevalence and relative risk of other autoimmune diseases in subjects with autoimmune thyroid disease. Am J Med. 2010;123:183.e1-9.

6. Stahl SM. Psychosis and schizophrenia In: Stahl SM. Stahl's essential psychopharmacology: neuroscientific basis and practical applications. 3rd ed. Rio de Janeiro: Guanabara Koogan; 2010. p. 168-217.

7. Stahl SM. Antipsychotic drugs. In: Stahl SM. Stahl's essential psychopharmacology: neuroscientific basis and practical applications. 3rd ed. Rio de Janeiro: Guanabara Koogan; 2010; p. 218-300.

8. Minzenberg MJ, Yoon JH, Carter CS. Schizophrenia. In: Hales RE, Yudofsky SC, Gabbard GO. The American psychiatric publishing textbook of psychiatry. 5th ed. Porto Alegre; Artmed; 2012. p. 431-82.

9. Nordyke RA, Gilbert FI Jr. Optimal iodine-131 dose for eliminating hyperthyroidism in Graves' disease. J Nucl Med. 1991;32:411-6.

10. DeGroot $L$ J Jameson JL. Endocrinology: adult and pediatric. Marinò M, editor. Graves' disease. 6th ed. Philadelphia: Elsevier Saunders; 2010. p. 1527-58.

11. Melmed S, Polonsky KS, Larsen PR, Kronenberg HM, editors. Williams textbook of endocrinology. 12th ed. Philadelphia: Elsevier Saunders; 2011. Section III: Thyroid, Chapter 12: Thyrotoxicosis. p. 362-405.

12. Fornaro M, Iovieno N, Clementi N, Boscaro M, Paggi F, Balercia G, et al. Diagnosis of comorbid axis-I psychiatric disorders among women with newly diagnosed, untreated endocrine disorders. World J Biol Psychiatry. 2010;11:991-6.

13. Gregory I. Mental disorder associated with thyroid dysfunction. Can Med Assoc J. 1956;75:489-92.

14. Radhakrishnan R, Calvin S, Singh JK, Thomas B, Krishnamachari $\mathrm{S}$. Thyroid dysfunction in major psychiatric disorders in a hospital based sample. Indian J Med Res. 2013;138:888-93.

15. Rønnov-Jessen V, Kirkegaard C. Hyperthyroidism - a disease of old age? Br Med J. 1973;1:41-3.

16. Snaboon T, Khemkha A, Chaiyaumporn C, Lalitanantpong D, Sridama V. Psychosis as the first presentation of hyperthyroidism. Intern Emerg Med. 2009;4:359-60.

17. Chittiprol S, Venkatasubramanian G, Neelakantachar N, Babu SV, Reddy NA, Shetty KT, et al. Oxidative stress and neopterin abnormalities in schizophrenia: a longitudinal study. J Psychiatr Res. 2010;44:310-3.

18. Cheniaux E, Landeira-Fernandez J, Telles LL, Lessa JL, Dias A, Duncan $T$, et al. Does schizoaffective disorder really exist? A systematic review of the studies that compared schizoaffective disorder with schizophrenia or mood disorders. J Affect Dis. 2008,106:209-17

\section{Correspondence:}

Dr. Pablo Eduardo Pereira Dutra

Department of Psychiatry

Centro Psiquiátrico do Rio de Janeiro (CPRJ)

Praça Coronel Assunção, s/n, Gamboa

20220-480 - Rio de Janeiro, RJ - Brazil

Tel./Fax: +55 (21) 2332.5676

E-mail: pablo.medicina@ufrj.br 